\title{
As figurações de rei e a caracterização de "puritano" e "papista" em Basilikon Doron
}

\author{
Alexander Martins Vianna
}

\section{Introdução}

Escrito quando se desenhava a polêmica decisão de Elizabeth I (1530-1603) de definir a sucessão do trono inglês para James VI da Escócia, o tratado Basilikon Doron $(1599)^{1}$ foi concebido como um livro de aconselhamento de pai (rei) para filho (príncipe). O título do tratado é uma latinização do grego Baбı入ıкòv $\Delta \tilde{\omega} \rho \circ v$, que significa "Dom Régio", ou seja, o dom de governar do rei. Em chave teológica protestante, isso equivale ao chamado divino que confere aos reis o dom de governar (Royal Gift em inglês). No entanto, para além de ser um manual ou espelho para um jovem príncipe, esse tratado serviu também como meio editorial de propaganda política favorável a James na Inglaterra, pois resumia a sua visão sobre pontos polêmicos, tais como: a "ameaça interna puritana", a ortodoxia da igreja episcopal e a "ameaça externa papista".

Assim, além das repisadas tópicas erasmianas da ética de governar, ${ }^{2}$ a figuração de James no discurso do tratado expõe o que deveria ser entendido como a sua visão sobre os seguintes assuntos: a origem divina da autoridade régia; a importância da sucessão hereditária do trono como meio de estabilidade política, o que significava evitar qualquer tipo de fator ou comportamento que pudesse conturbar a linha sucessória masculina do trono; a importância de se superar diferenças religiosas em matérias consideradas superficiais ("indiferentes") sobre liturgia e doutrina de fé, de modo a se valorizar o que seria considerado os fundamentos centrais de uma religião reformada; a ameaça à ordem interna pelos críticos puritanos rigoristas, entendidos como contrários à infalibilidade da Bíblia em nome da iluminação da consciência ("religião da luz interior"), o que conduzia a atitudes irreverentes em relação à autoridade régia e aos seus oficiais (civis ou eclesiásticos).

Desde o início da Reforma, doutos protestantes como Lutero (1483-1546) e Calvino (1509-1564) tiveram de lidar com consequências indesejadas de suas ideias relativas à fé interior è eleição: a autoconfiança exagerada da eleição e uma concepção radical da liberdade do cristão. De forma geral, aquele que se considera eleito sente que a graça divina é tudo que o distingue. A forma radical desse senso de autoconfiança e dignidade espiritual poderia criar uma espécie de "aristocracia espiritual" a qual poderia, no limite, contestar a propriedade, a submissão reverente à aristocracia mundana e a igreja episcopal. ${ }^{3}$ Portanto, a forma radical do senso de dignidade dos eleitos poderia colocar em risco a visão estática de mundo da igreja episcopal, assim como muitos dos dispositivos de controle social emergidos durante as reformas elisabetanas, como os tribunais eclesiásticos e a proibição de que os leigos pudessem pregar. ${ }^{4}$

$\mathrm{Na}$ racionalização teológico-política proposta em Basilikon Doron, a instabilidade provocada pelos puritanos rigoristas às instituiçôes religiosas, sociais, jurídicas e políticas abria brecha para a entrada de influências papistas. Portanto, o seu discurso nivela e interliga as duas ameaças, pois ambas são entendidas, entre outras coisas, como conduzidas por "sofistas" que arrogam a perfeição de sua fé e, por isso, prendem-se a disputas sobre detalhes doutrinais que seriam indiferentes para a exterioridade da fé (vida civil) e que tão somente serviriam para conturbar a ordem civil. Por outro lado, James é figurado como indiferente quanto aos aspectos externos secundários de manifestação da fé reformada, devendo todos os súditos se ater aos pontos fundamentais da fé.

$\mathrm{Na}$ concepção jacobita, os pontos fundamentais da fé estariam baseados (1) na infalibilidade da Bíblia, (2) no caráter divinamente inspirado dos poderes civis e eclesiásticos, (3) na negação do sacerdó- 
cio universal e (4) na afirmação da sacralidade específica do Dom Régio (Basilikon Doron). Partindo desse patamar de questóes, James sistematiza experiências e princípios que poderiam ser úteis para seu filho. Vejamos, então, nos itens que se seguem, o desenvolvimento das ideias político-teológicas do rei James.

\section{A figuração moral do Autor para o Leitor}

Considerando a sua intenção declarada de sistematizar as suas experiências para seu filho e de não prejudicar a possibilidade de sua sucessão ao trono da Inglaterra, James afirma, em sua carta ao leitor, que toda vez que se reportasse ao exemplo de sua mãe não visava inspirar em seu filho o espírito de vingança, o que bem demonstra que havia a intenção de publicar tal obra e torná-la um meio de propaganda política na Inglaterra. Logo em seguida, afirma ter a intenção de que todos os seus projetos futuros fossem avaliados a partir de suas ações do passado, pois entende que os livros seriam as vívidas ideias da mente de um autor. No entanto, uma vez em livros, as ideias também poderiam ser sujeitas a múltiplas apropriações.

Consciente disso, embora apelasse para o formulário retórico de que não era a sua intenção original expor seu livro à "hidra das opiniōes de diversos expectadores", James afirma que tenta evitar interpretaçōes equivocadas dos leitores ao escrever com "plainenesse, patience, and sinceritie" ("clareza, paciência e sinceridade"), ou seja, se coloca num patamar moral distinto dos "sofistas" ("puritanos" e "papistas/jesuítas/escolásticos"). Com isso, afirma a sua distinção estilística e moral em relação à dialética dos "puritanos" e "papistas" (com seu "hábito" de criar "polêmicas desnecessárias" em matérias doutrinais); por outro lado, esse tipo de figuração retórica que o rei cria para si também o situa como o antítipo moral do cortesão afetado por fórmulas retóricas empoladas. Deste modo, James cria para si uma aura de austeridade, demonstrando que não estaria sujeito a apelos de cortesãos bajuladores - e esperava a mesma atitude de seu filho. ${ }^{6}$

Além disso, James se caracteriza como rei sábio e prático, ou seja, como o protótipo do príncipe renascentista. Daí, afirma que não expressa conhecimento como um mestre-escola, que somente conheceria as matérias de governo por especulação e silogismos - ou seja, os relatos abstratos sobre a instituição do "Principado em geral" não serviriam para a instrução de uma jovem alteza social. Com isso, James justamente demonstra a preocupação erasmiana de escrever um curto tratado que fosse próprio à educação de um príncipe infante (que não suportaria ler uma obra muito extensa e abstrata). Por outro lado, James aproveita esse aspecto formal de sua obra para se caracterizar como um soberano continuamente envolvido nas matérias de seu ofício (e, portanto, sem "lazeres frívolos" e "sem tempo" para se dedicar a matérias excessivamente especulativas, como seria o caso dos "sofistas"). É essa expectativa moral exemplar que James retoricamente projeta sobre seu filho.

\section{O significado da Bíblia e como deve ser lida pelo príncipe cristão}

No primeiro livro, James trata dos deveres dos Reis perante Deus, estabelecendo uma relação implicativa entre hierarquia de poder, responsabilidade e pecado, afirmando para seu filho que sua alteza social não diminuiria a suas faltas; pelo contrário, em virtude de sua dignidade principesca, suas falhas seriam mais graves, pois, tendo recebido o mandato divino para governar seu povo, deveria figurar-se perante este com todo o brilho da santificação e retidão. Para tanto, o príncipe deveria saber refrear todas as suas paixões, ou ao menos saber configurá-las de forma útil para o seu ofício.

De forma coerente com isso, James afirma que os serviços de Deus seriam prestados - por intermédio dos homens - de duas formas principais: internamente, através da fé e da oração; externamente, através de ações no mundo que contenham o espírito de equidade em relação aos seus vizinhos. No entanto, todo louvor a Deus deveria estar de acordo com Sua vontade, tal como revelada na Bíblia, sendo sustentado pela fé e conservado pela consciência. Como James sabe que está falando generica- 
mente da Bíblia num contexto de tensão com os puritanos, continua a sua instrução indicando quais partes da Bíblia o infante poderia ter como principais, explicando o seu caráter e sentido teológico. Isso é importante para conhecermos qual é o seu entendimento doutrinal da Bíblia e como cria sentido prático ou método de leitura para ela, em contraste com os "puritanos".

Segundo James, toda a Bíblia foi ditada pelo Espírito Santo para instruir e regular toda a Igreja militante até o fim do mundo. Ela estaria dividida em duas partes: o Velho Testamento, cujo fundamento é a Lei Mosaica, que apresenta o pecado humano e contém a Justiça; o Novo Testamento, cujo fundamento é Cristo, que perdoa o pecado e contém a Graça. Por causa do pecado, nenhum homem seria capaz de manter-se espontaneamente na Lei, daí a importância da espada mundana da justiça, que seria encarnada pelos soberanos; por outro lado, Deus teria encarnado o Seu único filho na natureza humana para sofrer pelos homens e satisfazer a Sua justiça. Assim, considerando que o homem não poderia ser salvo pelos seus méritos pessoais, mas sim pela fé em Cristo, que é infundida por Deus, cada indivíduo deveria forçosamente se manter nos marcos da Lei, pois os mandamentos mosaicos seriam o fundamento divino que inspiraria os costumes e as leis civis, que tornavam possível a vida em comum até o Juízo Final.

Assim, são ratificados o império da graça (em detrimento das obras/mérito pessoal) e a infalibilidade da Bíblia (em detrimento da iluminação interior), mantendo uma dualidade complementar entre Lei e Graça que se tornara um verdadeiro sistema lógico no pensamento teológico protestante desde a Instituição da Religião Cristã, de João Calvino (1509-1564). Assim, James já aponta para uma solução doutrinal que distinguiria as suas expectativas sobre a Igreja da Inglaterra daquilo que ele caracteriza como "erro" puritano ou papista: ninguém deve arrogar eleição e, em função disso, supor ser possível, neste mundo, nutrir uma perfeição angélica por mérito pessoal e, por conta disso, desrespeitar as hierarquias sociais, as autoridades (civis e eclesiásticas) e as leis civis em nome da "pureza de consciência" ou da "fé". Enfim, Lei e Graça seriam dádivas divinas para o homem depois da Queda e, portanto, deveriam ser entendidas como complementares devido à natureza paradoxal do Homem.

Ao instruir a leitura da Bíblia, James afirma que o fundamento da graça encontra-se nas histórias que envolvem nascimento, vida, morte, ressurreição e ascensão de Cristo, tal como largamente interpretadas e contidas nas Epístolas dos Apóstolos. E a prática e o desvio da fé, assim como a história dos primeiros progressos da Igreja, poderiam ser encontrados nos Atos dos Apóstolos. Caso o infante quisesse conhecer seu pecado por meio da Lei, deveria ler o Livro de Moisés. Caso quisesse conhecer seus comentários, deveria ler os Profetas, o Livro de Provérbios e Eclesiastes, "escritos com grande sabedoria por Salomão", que serviriam não apenas para a instrução da Lei de Deus, mas também forneceriam grande repertório de sentenças e preceitos morais, assim como, de preceitos de bom-senso (naturall wisedome), para todas as coisas que tocassem a conversação douta no mundo com os grandes Filósofos e Poetas. Assim, de forma erasmiana, James propõe uma leitura moral e poética de partes específicas da Bíblia que as nivela à mesma função educativa de tratados morais clássicos.

Ora, seguindo tal proposição, se o príncipe quisesse conhecer como os homens de bem são recompensados e os perversos punidos, deveria ler algumas partes do Livro de Moisés, juntamente com as histórias de Josué, Juízes, Esdras, Neemias, Ester e Jó, mas especialmente os Livros dos Reis e as Crônicas, que serviriam como um catálogo ou espelho dos bons e maus Reis (espelhos de príncipes). Por outro lado, se o príncipe quisesse conhecer a doutrina da vida e morte de Cristo Redentor, deveria ler os Evangelhos, mediados pelas Epístolas dos Apóstolos. Com os Atos dos Apóstolos, o príncipe conheceria as práticas dessa doutrina entre as personalidades da Igreja primitiva. Em todos esses pontos, observamos as mesmas ênfases de leitura bíblica propostas por Calvino, em Instituição da religião cristã e em Comentários à Bíblia. ${ }^{7}$

Portanto, tudo é exposto pelo rei numa chave de austeridade para fazer coincidir a sua excelência moral com a excelência de sua condição social, pois a sua posição na hierarquia estamental de poder obrigaria o príncipe a ser o mais excelente modelo para seus súditos. Não sem sentido, James instrui que o seu filho deveria ler a Bíblia com um coração casto e santificado; deveria admirar reverentemente as partes obscuras quando não as entendesse, culpando somente a sua própria incapacidade; deveria ler 
com regozijo as partes claras e estudar cuidadosamente aquelas que parecessem difíceis de algum modo. Fundamentalmente, o príncipe deveria considerar que a Bíblia seria a melhor intérprete de si mesma, não devendo buscar nada além daquilo que ela contém, pois não deveria esforçar-se para conhecer aquilo que a vontade de Deus quis manter em segredo.

Com isso, observamos uma crítica à "religião da luz interior" (ameaça puritana) e aos silogismos do método escolástico (ameaça papistaljesuita, algumas vezes, identificada com os doutos da Universidade de Oxford). Portanto, tudo que seria necessário ao homem conhecer para a sua salvação já teria sido revelado na Bíblia. Por isso, o príncipe deveria deleitar-se em ler aquelas partes que melhor servissem para a sua instrução, rejeitando as tolas curiosidades a respeito de genealogias e contendas doutrinais, que seriam vãs e nada trariam de proveito ao governo. Afinal, a "corrente de ouro" que prenderia a alma do fiel a Cristo seria um dom gratuito de Deus, que deveria ser sustentado pela oração, que não seria outra coisa senão uma conversa amigável com Deus. Assim, James ratificava pontos doutrinais (artigos 25, 27 e 28) contidos nos XXXIX Artigos (1571) da Igreja da Inglaterra.

\section{Prece, superstição e consciência: To be or not to be Precise}

James recomenda ao seu filho que, ao fazer suas orações, não deveria agir com Deus como um estranho que reza conforme regras alheias aos livros sagrados (papistalescolástico); por outro lado, não deveria ser excessivamente familiar, como fariam os "farisaicos puritanos", pois deveria dirigir-se a Deus com toda a reverência, não tendo por objetos de orações as coisas indignas - tais como vingança, luxúria ou coisa parecida -, porque esse tipo de oração não viria da fé, mas da carne. Coerentemente com isso, James define a consciência como a "luz de conhecimento que Deus plantou no homem" e que serviria para atormentar as almas perversas. E lembra que a melhor forma de o príncipe não ser julgado seria julgar-se sinceramente (autoexame periódico da consciência) e, de acordo com a sua autocensura, reformar as suas ações o quanto pudesse, evitando contrariar a sua consciência, pois um pequeno pecado cometido voluntariamente, ou seja, com a deliberada resolução de romper os freios da consciência, é muito mais grave perante Deus do que um grande pecado cometido durante uma paixão súbita, quando a consciência está adormecida.

Para o príncipe manter a sua consciência livre da doença da superstição, deveria evitar dois extremos: assentar a segurança de sua consciência em seus próprios engenhos (conceits) e oníricas revelações, tal como fariam os anabatistas/puritanos; assentar a mesma nas opiniōes dos grandes doutores da Divindade, tal como fariam os papistas. Trata-se de uma figura retórica que vemos se repetir desde, pelo menos, as primeiras edições de $A$ Instituição da Religião Cristã, de Calvino, qual seja: tratar como superstição qualquer dedução em matérias de fé e doutrina que não se assente nas partes claras da Bíblia, pois, neste caso, são obras da imaginação humana, de sua carnalidade idólatra. Como alternativa a tais "erros" puritanos e papistas, o príncipe deveria fundamentar-se somente na Bíblia, mas sabendo estabelecer a diferença entre os pontos relativos à salvação e às coisas indiferentes; entre a substância e as cerimônias; entre a expressa vontade de Deus em Suas palavras e as invençôes humanas.

Como tudo o que seria necessário para a salvação estaria contido na Bíblia, tudo o que não fosse expressamente permitido ou proibido no livro de Deus não deveria ser conduzido com exagerado rigor (cannot be over precise), mas sim seguir os usos e as necessidades dos tempos. Por isso, se os clérigos advertissem o príncipe sobre algum assunto ou determinada ação claramente proibido pela Palavra, o príncipe deveria reverenciá-los e obedecê-los como portadores da mais alta divindade. No entanto, se passassem dos limites, substituindo a Palavra por suas próprias fantasias e colorindo seus interesses particulares com zelo fingido (seemer), o príncipe deveria enxergá-los como homens vãos que estariam extrapolando os limites de seu ofício e, com grave autoridade, deveria reconduzi-los novamente para a ordem.

No entanto, seria fundamental para um príncipe evitar a soberba de exibir ou glorificar a sua própria divindade, pois deveria ser humilde e reservado ao rezar e doar a sua alma a Deus. Por outro lado, 
em todas as suas ações visíveis, deveria demonstrar que segue os mandamentos de Cristo, de modo a evitar que recaísse sobre si a suspeita de hipocrisia suja e orgulhosa, assim como de dissimulação engenhosa. Enfim, como recomenda James, Deus deveria estar abundante no coração do príncipe, mas deveria ser poupado em sua boca. Nesse argumento, puritanos e papistas são estereotipados como hipócritas, visto que tentariam publicamente figurar-se over precise em matérias de consciência. No entanto, dada a paradoxal condição humana, não conseguiriam mais do que aparentar hipocritamente a perfeição (condição de seemer/hipócrita), com a única intenção de serem arrogantes em relação às autoridades divinamente constituídas para manter o homem em paz civil.

É interessante observar que, no vocabulário das peças do corpus shakespeareano, termos como precise e seemer, assim como suas derivações adverbiais, substantivas e adjetivas foram recorrentemente utilizados para caracterizar ou estereotipar um personagem como supersticioso, idólatra, carnal e/ou puritano hipócrita. Essa forma ou função do termo precise no vocabulário teatral inglês é identificável desde a década de 1570, ou seja, o período de estabilização doutrinal da forma episcopal da Igreja da Inglaterra. ${ }^{8}$ Portanto, trata-se de um estereótipo que é anterior aos escritos de James I, que simplesmente aciona em Basilikon Doron um repertório de fácil identificação por um frequentador assíduo dos teatros ingleses. É importante também notar que, a partir do final de 1603, James I iria se tornar patrono da companhia teatral de Shakespeare.

\section{Tirania, justiça, lei, linhagem e clientela}

No segundo livro de Basilikon Doron, James trata especificamente dos deveres dos reis no exercício de seu ofício, diferenciando o bom Rei do Tirano. James aconselha o seu filho a visitar as principais partes de seu reino pelo menos uma vez por ano, mesmo que, no futuro, seus domínios se ampliassem e incluíssem a Inglaterra. E quando estivesse numa localidade, o rei deveria ouvir diretamente as queixas de seus súditos e deliberar sobre as matérias principais. ${ }^{9}$ Por isso, deveria manter conselhos ordinários ("iustice-seates") em todo reino e compostos por seus próprios moradores. Por outro lado, ao tratar com outros príncipes, James aconselha o seu filho a agir honesta e amigavelmente, como se fossem seus irmãos, mantendo a sua palavra, mesmo que isso significasse ferir a si mesmo. No entanto, um rei não deveria socorrer príncipes rebeldes, mas tão somente os legítimos que estivessem com problemas.

Por outro lado, como pessoa pública, um rei seria a cabeça do corpo político e, portanto, não poderia dispor de si mesmo ao seu bel prazer. Por isso, não se poderia envolver em querelas que somente pudessem ser resolvidas por meio de duelos, pois, além de tal prática ser ilegal entre particulares, compromete toda a segurança da Commonwealth quando envolve pessoas públicas. Embora fosse importante um rei ter fama de corajoso e magnificente, não deveria agir diariamente como um soldado e expor-se precipitadamente a todo tipo de perigo, pois a riqueza de seu povo dependeria de que seu rei se conservasse para seu povo e não para seus próprios proveitos particulares ou caprichos. Em todo caso, uma guerra justa e honrosa seria mais tolerável do que uma paz desvantajosa e desonrosa.

Segundo James, o bom Rei reconhece a si mesmo como ordenado para seu povo, tendo recebido de Deus o fardo de governar; o tirano, por outro lado, pensa que o povo fora ordenado para seu proveito pessoal, como se fosse uma presa de suas paixões e apetites desregrados. O bom Rei sojigaria os seus próprios apetites e suas paixões particulares, pois o maior de seus contentamentos seria a prosperidade e segurança de seus súditos. O Tirano, por sua vez, nunca estaria em segurança, pois constrói o seu poder alimentando dissensões e criando miséria entre seus súditos.

James trata também da relação entre rei e parlamentos, lembrando ao seu filho que os parlamentos foram ordenados para fazer Leis, de forma que os reis não deveriam desrespeitar tais instituições, que seriam as mais altas cortes dos reinos. No entanto, o parlamento deveria ser convocado somente em caso de necessidade de se criar novas leis - fato que, preferencialmente, deveria ser raro. Portanto, não haveria equivalência entre a função do parlamento no Antigo Regime e o sentido liberal-constitu- 
cional de divisão de poderes e leis, pois o parlamento no Antigo Regime não seria um poder legislativo permanente e paralelo a um poder executivo, mas um órgão consultivo somente formado por convocação régia in casus necessitas, visando resolver demandas não contidas na tradição e não previstas como atribuições do poder soberano arbitral dos monarcas. Em todo caso, é bom lembrar, as leis oriundas de parlamentos/cortes no Antigo Regime formavam um repertório casuístico para ação, cujo efeito seria temperado pelos poderes arbitrais relativos e soberanos. ${ }^{10}$

Assim, modelarmente, em matéria de leis, o melhor soberano é aquele que não inova em criações unilaterais, pois isso é sempre visto nos tratados sobre a arte de governar como um mal usado como último recurso, ou seja, em situaçôes muito extraordinárias de necessidade pública (casus necessitas), pois, em tais situações, a "necessidade faz a lei". Quando observamos a sutileza doutrinal desses argumentos, podemos notar o quanto conceitos hodiernos de chave constitucionalista liberal, como "absolutismo", mais atrapalham do que possibilitam entender a especificidade das dinâmicas relações de autoridade entre rei e leis no Antigo Regime. ${ }^{11}$

Segundo James I, os reis e seus súditos deveriam lembrar-se sempre de que o cargo régio pertence exclusivamente a Deus, que ordena os reis para fazerem a justiça nos reinos da Terra em Seu lugar. Portanto, em relação a Deus, é como se os reis fossem arrendatários vivos do ofício régio. Daí, na sua relação com as riquezas de seu reino e súditos, um rei não poderia abusar no uso daquilo que não lhe pertencia. Por isso, em caso de necessidades decorrentes de guerras ou outras questóes públicas extraordinárias que impelissem o rei a cobrar subsídios, deveria utilizá-los exatamente naquilo para o qual foram levantados. No entanto, adverte James, um rei deveria buscar tais subsídios muito raramente e, tal como sugere Aristóteles, usar a si mesmo como fidus depositarius para seu povo. Em todo caso, antes de tomar tal decisão, um rei deveria agir com sabedoria, sabendo distinguir entre relatórios falsos e verdadeiros a respeito das necessidades do Estado. Para tanto, deveria considerar a natureza, os antecedentes e os interesses das pessoas que fizessem tais relatórios que, na prática, tornavam-se os olhos ou ouvidos dos reis.

Portanto, para não se confundir com um tirano, um príncipe não deveria se esquecer de pôr limite moral à sua vontade pessoal, pois isso estaria implicado com o mandato divino do ofício régio. Por isso mesmo, James lembra a seu filho que Deus sempre olhará para as intenções internas de todas as ações de um soberano; que, na prática de governo, deveria dosar adequadamente justiça e misericórdia, considerando os comportamentos passados das pessoas que cometeram algum crime e que estiveram sob seu julgamento ou serviço. Em relação às ofensas contra a própria pessoa e autoridade do príncipe, James reserva ao seu filho a escolha de punir e perdoar conforme o seu próprio coração (i.e., com bom-senso que desemboque em resolução uniforme e constante da consciência), as circunstâncias da ofensa e a qualidade do ofensor.

Enfim, para fazer a justiça com misericórdia, um príncipe deveria agir com equidade na prática das leis e dos costumes, o que significa não ser "over precise" na sua execução, pois, caso contrário, poderia dar um efeito tirânico para seu uso. Como podemos notar, James destaca a justiça como a virtude principal que pertence propriamente ao ofício régio. Como a prática da justiça daria significado para as leis, seria uma temeridade para os bons súditos de um rei que elas fossem interpretadas em sentido literal. ${ }^{12}$ Como sabemos hoje, numa sociedade formada por corpos de privilégios e por estruturas e dinâmicas estamentais de configuração de vínculos sociais e de expectativas de práticas sociais, o poder soberano deve saber temperar os efeitos das leis, considerando, em caso de punição, o tipo de delito, o tipo de dano provocado, as circunstâncias, a idade, o sexo e a condição social do malfeitor.

No entanto, James lista algumas formas de crime em relação às quais o seu filho nunca deveria conceder perdão: bruxaria, profecias sobre o rei e sua família, assassinato premeditado, incesto (especialmente no interior dos graus consanguíneos), sodomia, envenenamento, falsa cunhagem de moedas, assim como escritos e rumores falsos e irreverentes de homens maliciosos contra os pais e antepassados do soberano. ${ }^{13}$ Sobre este ponto, James continua o seu argumento lembrando a seu filho que todos os reis teriam algum tipo de falta que, privadamente perante Deus e sua consciência, deveria servir como 
exemplo para meditação e, deste modo, corrigir a sua própria pessoa, mas tais faltas - que deveriam ser objetos secretos de autoexame periódico na consciência do príncipe - não deveriam servir de assunto (subject) para seus súditos (subjects). ${ }^{14}$

Com isso, afirma-se um pressuposto que é repetido desde as críticas de Martinho Lutero (14831546) aos anabatistas, ${ }^{15}$ qual seja: a consciência do soberano deveria ser somente mensurada ou submetida a escrutínio (made subject) do próprio soberano e de Deus. Portanto, súditos (subjects) que pretendessem colocar o soberano sob escrutínio (to make subject) seria uma insolência inaceitável que deveria ser severamente reprimida. Como adverte James, muitos súditos insolentes poderiam pretender, engenhosamente, manchar a sua raça e roubar a afeição do povo sobre a sua posteridade. Então, rumores e profecias publicamente proferidos contra a dinastia dos soberanos deveriam ser entendidos como crimes de lesa-majestade, pois criariam sedições ou perda de confiança em relação à dinastia governante. ${ }^{16}$

Ora, esse tipo de conselho não deve nos surpreender, pois, afinal, trata-se de uma racionalização teológico-política centrada no paradigma de valor linhagista-estamental de mensuração de mérito e responsabilidade social. Por isso, podemos observar James usar como recurso retórico o seguinte silogismo: se alguns súditos podem amar um rei, não podem odiar a árvore de onde veio; da mesma forma que seria monstruoso um homem amar seu filho e odiar os seus pais. Portanto, difamar e tornar odiosos os pais são formas de trazer desprezo para o filho. Aliás, na edição impressa de 1597 da peça shakespeareana Ricardo III, podemos justamente observar que uma das tópicas de caracterização do tirano diabólico e, portanto, sem limites de consciência, é a difamação da própria linhagem como um meio de atingir o poder. Como consequência, todo o reino é assolado por sedição e desordem civil - e o próprio soberano tirânico-herodesiano não consegue se sentir verdadeiramente seguro para desfrutar de seus ganhos diabólicos. ${ }^{17}$

Para um soberano ser a perfeita encarnação da justiça, o julgamento régio não poderia ser uma presa fácil de razôes privadas e de bajulações. ${ }^{18}$ Por isso mesmo, James aciona a tópica da "justiça cega e amigável" em seu discurso para aconselhar o seu filho a não agir, no exercício de seu ofício, como se pretendesse beneficiar amigos ou se vingar de desafetos pessoais. Coerentemente com isso, James adverte a seu filho a importância de também estar atento aos súditos de alto nível social que, em suas terras, venham a oprimir os pobres. Embora esse tipo de crime não fosse imperdoável, o rei nunca deveria deixar de proteger o pobre e entender como função de alta honra reprimir os opressores soberbos de seus súditos mais desafortunados. ${ }^{19}$

Por conta disso, James adverte o seu filho que as Terras Altas e os confins do reino da Escócia estariam cheios de Grandes Lordes e chefes de clãs que, por não encontrarem dificuldade para oprimir os desafortunados, agiriam como se não tivessem um soberano. Para equilibrar essas relações locais de poder, James imagina um projeto de colonização que pudesse promover o refino progressivo dos hábitos e costumes dos súditos highlanders. Em sua estratégia, imagina que a instalação de colônias de novos súditos diretamente subordinados ao rei possibilitaria implantar progressivamente a civilidade na região. $\mathrm{Na}$ verdade, tratava-se da estratégia imperialista clássica de dividir para imperar: para ampliar a rede clientelar régia e atenuar ou subordinar as redes clientelares dos antigos potentados highlanders, a criação de maciços populacionais de novos colonos, cujo status jurídico dependeria diretamente do soberano, teria como efeito a atenuação dos usos e costumes locais que até então garantiriam o poder das antigas linhagens nobres highlanders.

\section{Caracteres sociais e balança de poder}

Ao informar a seu filho que os súditos da Escócia estão divididos em três estamentos, James também recorda que, independentemente de sua posição de nascimento, há súditos bons e maus em todos os estamentos, pois todos estão suscetíveis às "doenças naturais" ${ }^{20}$ do Orgulho, da Ambição e da Avareza, que, segundo a sua opinião, sempre conturbaram e provocaram a decadência de reinos e igrejas desde o começo do mundo. Tais enfermidades teriam atingido, inclusive, a "igreja papista" dentro e fora da 
Escócia, assim como, estiveram fortemente presentes durante a sua menoridade, quando afloraram chefes de facções (puritanos) que se consideravam "tribunos da plebe" e que, em sermões populares, caluniavam o rei infante, não porque tivesse algum vício ou mau em si, mas tão somente porque era rei para eles, o maior dos males e inimigo da liberdade da Igreja.

Segundo James, a experiência demonstraria que as demandas puritanas por paridade de culto e ensino religioso apenas serviriam para evidenciar que a igualdade é a mãe da confusão e inimiga da unidade. Assim, a experiência de James demonstraria que, uma vez estabelecido o governo Episcopal, o estado civil-político alcançaria de novo a estabilidade. Por isso mesmo, James diz que seu filho deveria restabelecer a velha instituição dos três estamentos no Parlamento da Escócia e combater os puritanos, pois seriam pragas para a Igreja e a Commonwealth: irreverentes com juramentos, vínculos e promessas, inspirariam tão somente calúnia e sedição, fazendo de suas próprias imaginações (sem qualquer fundamento na Palavra) o enquadramento de sua consciência. Como observamos em outra seção, no argumento moderado calvinista, isso era equivalente a ser movido por superstição e idolatria (de mente e coração).

Para James, o príncipe deveria promover o ensino religioso conforme a Palavra, fundando seminários e estabelecendo suficientes proventos para a sua manutenção. No entanto, a ação de reprimir a ameaça puritana deveria ser feita de tal forma que o rei não sofresse, depois de tudo, a ameaça soberba e orgulhosa do poder eclesiástico. Ambos os extremos de ameaças à autoridade régia deveriam ser evitados. Por isso, deveria haver um cuidado especial na escolha dos padres para as paróquias e na ordenação dos bispos, pois as suas qualidades morais, intelectuais, fidelidade e retidão no ofício deveriam ser de tal monta que não abrissem precedência para calúnias ou quebras da cadeia de autoridade, já que os poderes civis e eclesiásticos na Escócia e na Inglaterra tinham como cabeça o rei.

Ao chegar a esse ponto de seu argumento, James aborda a forma como o príncipe deveria equilibrar as relações de poder e autoridade em relação aos nobres do reino, lembrando que a nobreza estaria obrigada a obedecer às leis e a manter a paz entre seus vizinhos (conforme as leis). Baseando-se em sua experiência, James afirma que a doença mais comum entre os nobres seria o arrogante conceito que teriam de seu poder e sua grandeza, que os faria pensar que a sua honra assentar-se-ia em cometer três tipos de iniquidades: (1) oprimir e controlar a vida de seus vizinhos desfavorecidos, obrigando-os a entrar em seus serviços; (2) proteger seus serviçais e dependentes de qualquer ofensa, como se fossem os responsáveis pelas leis, ou, pior ainda, armá-los para praticarem vinganças contra um vizinho; (3) expulsar um vizinho e seus parentes de suas terras somente porque são contrários aos seus desmandos e às ofensas de seus parentes e serviçais, o que desrespeita Deus, o Rei e a Commonwealth.

Para equilibrar as relações de poder no reino, James sugere que seu filho deveria dar acesso à sua pessoa para qualquer súdito honesto, em vez de empregar os grandes Lordes como intercessores, pois "intercessão para Santos é Papismo". Além disso, o rei deveria impor a sua lei contra a bárbara prática das vinganças, promovendo punições exemplares contra os infratores brigões (a começar por aqueles que teriam a sua afeição pessoal) e proibindo o uso de armas e pistolas. No entanto, James adverte que o príncipe deveria evitar enfraquecer e desprezar a nobreza, pois seguir esse extremo foi o grande erro de seus avós. Afinal, o príncipe deveria considerar que a virtude quase sempre segue o sangue nobre e, portanto, deveria honrar aqueles membros da nobreza que fossem obedientes às leis e humildes perante o rei, empregando-os nos negócios mais importantes, pois seriam bons exemplos para os demais súditos.

No entanto, James assinala que os maiores estorvos para a execução das leis em seu país seriam os Shirefdomes e Regalities hereditários ${ }^{21}$ que, estando nas mãos de grandes nobres, provocariam estragos por todo o país. Como não haveria remédio imediato para resolver tais transtornos sem criar novos, James recomenda que seu filho deveria ficar atento para punir seus potentados com tudo que as leis permitam na Escócia e, quando algum dentre eles viesse a vagar, não deveria concedê-los novamente de forma hereditária, tal como já seria costume na Inglaterra. Deste modo, se o infante viesse a ser rei de ambos os reinos, adverte James, poderia proceder de forma igual nos dois domínios. 
Quando se refere ao terceiro estamento, James afirma que este é composto pelos mercadores e artesãos, que ele chama de "nossos burgueses", que não deveriam ser confundidos com os pequenos barões, que conformavam a parte inferior da Nobreza. James afirma que os burgueses sofreriam as suas "próprias enfermidades": os Mercadores, por exemplo, pensavam que toda a Commonwealth foi criada para seu próprio proveito e prosperidade, cujos ganhos legais com o comércio os enriquecia à custa do povo. Com seus negócios, segundo James, os Mercadores levavam as coisas necessárias para fora do reino e, algumas vezes, traziam coisas desnecessárias. Eles seriam também a causa principal da corrupção da moeda. Aqui, a racionalização financeira de James segue aquela corrente de sua época: o metal precioso é a base da riqueza.

Nesses termos, se um mercador traz "produtos desnecessários" (manufaturas de luxo do exterior) ao reino, provoca a saída de metais preciosos. Ora, seguindo essa lógica, James afirma que o príncipe deveria contentar-se com o trabalho dos artesãos, por mais caro ou ruim que isso fosse inicialmente, pois, se fossem adequadamente controlados, poderiam provocar o florescimento de riqueza e conforto, tal como acontecera com a Inglaterra desde que artesãos estrangeiros se estabeleceram em suas cidades. Assim, James recomenda a seu filho atrair os artesãos estrangeiros também para a Escócia, o que significaria provocar a entrada de metais preciosos em tal reino por meio do comércio das manufaturas, ou simplesmente evitar que tais produtos de alto valor agregado fossem buscados no exterior, provocando a sangria de metais do reino.

Ao continuar a caracterização de seus súditos, James identifica uma falha comum a todos aqueles de origem simples: julgar e falar precipitadamente de seu Príncipe, por estarem sempre desejosos de novidade. Para aplacar tal demanda e reforçar os laços de amizade dos súditos entre si e com o rei, James recomendava que seu filho reservasse alguns dias do ano para deleitá-los com espetáculos públicos, festivais, peças teatrais, jogos honestos e exercícios de armas. Tudo isso configurava o solace régio, que os puritanos mais rigoristas condenavam..$^{22}$ Segundo James, tais formas de contentamentos para os súditos seriam costume de todos os estados bem governados. Ao afirmar isso, James demonstrava o cuidado de não ser confundido com "reis satíricos" das críticas puritanas.

Por fim, coerentemente com seu tratado Demonologia (1597), James recomenda a seu filho para pessoalmente não se importar com profecias, visões e sonhos proféticos, pois tudo isso teria cessado desde o advento de Cristo. No entanto, como já foi dito, entendê-los como mero fruto da imaginação humana e, portanto, como coisas indiferentes para as verdades da fé, não significa que o rei deveria manter indiferença em relação aos súditos (subjects) que tornavam a dinastia régia o seu assunto (made subject), pois poderiam ter efeitos danosos para a autoridade política entre os súditos mais supersticiosos. Em todo caso, seria indigno de um cristão (mais ainda, de um rei) ${ }^{23}$ fiar-se em profecias, visões e sonhos proféticos, porque isso demonstraria sua ignorância da Palavra. Assim, como James considera que os súditos vulgares seriam muito suscetíveis a tais engodos, seria perigoso um soberano deixar sem punição aqueles insolentes (particularmente os puritanos) que, desrespeitando a prerrogativa do estamento clerical na profissão da Palavra, fizessem pregações enquadradas por suas imaginações, como se fossem santos ou profetas, pois isso somente afastaria os súditos da verdade infalível existente nas partes claras da Bíblia.

\section{A figuração oeconômica do bom rei}

Segundo James, um bom Rei deveria saber equilibrar adequadamente o cetro da justiça com o seu papel de projetar o seu poder sobre os seus domínios, associando a isso o exemplo de uma vida virtuosa, que deveria se refletir em sua própria pessoa e nas pessoas que comporiam a sua Corte e a sua companhia pessoal. Afinal, o povo não teria como saber o que se passa no coração do príncipe; apenas poderia julgar aquilo que alcançasse com os olhos, ou seja, a aparência externa de suas ações, seus serviçais e suas companhias. Por isso, um bom Rei deveria ter sempre o cuidado de governar adequadamente os seus serviçais, já que sobre eles o soberano exerceria a dupla função de governante Político e Econômi- 
co. ${ }^{24}$ Além disso, seguindo a prerrogativa de sua posição, os serviçais de um príncipe jovem deveriam ser nobres tanto de sua mesma idade - que seriam educados em sua companhia - quanto homens de sabedoria, experiência e discrição/discernimento.

Daí, em relação às nobres companhias jovens que poderiam cercar um príncipe, James define que seus méritos deveriam ser considerados a partir da mística do sangue: se seria certo afirmar que a alma seria imediatamente criada por Deus e infundida a partir de cima, também seria certo afirmar, segundo James, que as virtudes e os vícios seriam quase sempre transferidos de pais para filhos cuja herança correria através do sangue e atingiria a semente. Por isso, um rei deveria assegurar que as companhias do príncipe viessem de uma raça honesta e verdadeira, que não viessem de casas manchadas pela falsidade e sedição.

James lembra a seu filho que a primeira rebelião que sofrera acabou por obrigá-lo a fazer grande alteração no quadro de seus serviçais. Disso tirou a lição de que, ao escolher seus serviçais na Corte, deveria considerar as suas qualidades (sangue nobre, sabedoria, honestidade e boa consciência) e as necessidades do governo, independentemente dos apetites particulares dos homens. Para tanto, deveria livrar a sua Corte dos serviçais aduladores, facciosos e brigões, que seriam uma verdadeira praga para todo Príncipe e a ruína dos estados. Por outro lado, para evitar a inveja e sedição das principais casas do reino, um rei nunca deveria colocar um estrangeiro em qualquer ofício principal do Estado; da mesma forma que não deveria utilizar um único homem, por mais qualificado que fosse, no desempenho de várias funçôes. ${ }^{25}$

A preocupação de James com as companhias do príncipe também se reverbera em outra: a necessidade de manter seu corpo impoluto até o casamento, já que um príncipe não poderia dispor de seu corpo como se fosse um bem particular. Ao tratar desse assunto, James nos fornece muitos indícios sobre a forma como pensa a relação entre os sexos, a descendência, a luxúria e o adultério, associando todos esses temas às necessidades políticas do Estado. Um príncipe que fosse dado a excessos de luxúria, por exemplo, além de ser mau exemplo, comprometeria sua descendência para o trono, pois poderia adquirir uma doença venérea ("mal francês"/sífilis), o que causaria a sua infertilidade ou mesmo impotência. Aliás, outro revés da luxúria do rei seria gerar descendentes bastardos. James usa o exemplo de seus avós para justamente demonstrar a seu filho o quanto a luxúria (ou, depois do casamento, o adultério) poderia ser ruinosa para a sucessão dinástica legítima, pois descendentes bastardos de um rei sempre poderiam ser um polo de instabilidade e rebelião contra a autoridade legítima de um príncipe herdeiro.

Por fim, retomando o clássico tema das virtudes cardeais, James adverte a seu filho que Deus seria o autor de todas as virtudes, tendo imprimido-as na mente dos homens através da luz da natureza. Por isso, perante os seus súditos, um rei deveria resplandecer todas as virtudes e a honestidade por meio de seus atos. Não sem sentido, James afirma a seu filho que a Temperança seria a rainha de todas as virtudes, explicando que não se trataria apenas de entendê-la como moderação no gosto e tato social (polidez cortesã), tal como pensaria a interpretação vulgar, mas sim ter a "sábia moderação" (wise moderation) das afeições e paixões. Por isso mesmo, a Clemência, a Magnanimidade, a Liberalidade, a Constância, a Humildade e, fundamentalmente, a Justiça deveriam ser utilizadas com "sábia moderação" pelo rei para não se tornarem injúrias ou ofensas para seus súditos. Os mesmos valores e as virtudes deveriam nortear a maior das alianças do rei: o casamento.

Segundo James, o casamento teria três causas centrais, definidas por Deus, e três causas acessórias. As três causas ordenadas por Deus seriam: conter a luxúria; realizar a procriação; possibilitar que o homem tivesse a ajuda de sua esposa, pois a mulher seria ordenada para ser o apoio em vez do estorvo do homem. As três causas acessórias seriam: a beleza, a riqueza e a amizade, que seriam todas abençoadas por Deus. No entanto, beleza sem generosidade, riqueza sem sabedoria e grande amizade sem graça e honestidade seriam somente máscaras para infinitas misérias.

Nessas consideraçôes, James tão somente seguia o que era comum em outros tratados protestantes sobre o casamento, que não era um sacramento, pois fora dado ao homem por Deus somente para garantir uma posteridade impoluta e saciar, com legítima moderação, a sua inevitável luxúria. Por isso, a beleza e a graça seriam necessárias para que houvesse suficiente atração no casal para gerar descendên- 
cia, mas tudo isso estaria perdido se não houvesse uma honesta amizade, cumplicidade e generosidade na aliança. Portanto, diferentemente do que seria proposto como modelo moral na Era Vitoriana, os tratados de casamento dos períodos elizabethano e jacobita deixariam claro que a busca do prazer carnal no casamento - com a devida moderação, pois os esposos não deveriam tornar-se ídolos um do outro seria necessária para a manutenção dos laços do casal e para a geração de descendência, particularmente enquanto os esposos fossem ainda jovens. ${ }^{26}$

Além disso, na escolha da esposa, o príncipe deveria cuidar para que fosse completamente de sua mesma religião e que seu nível e outras qualidades fossem compatíveis com o status do rei, devendo observar se não teria educação viciosa e más condiçôes. Tudo isso seria necessário porque esposa e marido seriam uma única carne e, portanto, rei e rainha deveriam figurar unidade para os seus súditos. Portanto, deveria se prevenir contra qualquer situação que alimentasse ou suscitasse dissensóes entre seus súditos: desacordos em religião e costumes, entre os padres do rei e da rainha, na educação dos filhos etc. Afinal, o exemplo de unidade deveria partir da própria casa régia para servir como inspiração para seus súditos. ${ }^{27}$

Portanto, o rei deveria ser hábil em moldar a sua esposa conforme as suas necessidades: comandá-la como seu Senhor; regrá-la como seu pupilo; satisfazê-la em todas as coisas razoáveis; tratá-la com a consideração que se reserva aos bons aliados; ensiná-la a não ser curiosa sobre matérias que não lhe pertenciam; lembrá-la de que o marido é a cabeça e a esposa o corpo; ensiná-la que o esposo deve comandar e a esposa obedecer. Por outro lado, seguindo a distinção de gênero, James recomenda a seu filho que nunca envolvesse a sua esposa no governo político da Commonwealth, incumbindo-a somente do governo da casa régia; mas, mesmo nesse caso, tudo deveria ser submetido à direção do marido. Além disso, o futuro rei deveria garantir companhias boas e castas para sua esposa, pois a mulher seria o sexo mais frágil e, portanto, mais suscetível à má influência. Justamente por isso, o esposo deveria ter certa paciência com as paixões da esposa, sempre a conduzindo para a boa razão, de forma que aprendesse a receber as censuras do marido com reverência e agradecimento.

James também lembra, tomando o exemplo bíblico de Isaac, que seu filho deverá deixar seus reinos para seu filho mais velho, provendo os demais filhos apenas com possessôes particulares - isso significa, tacitamente, não ter ou reconhecer nenhum descendente bastardo. Afinal, se um rei dividisse o seu reino em domínios políticos para todos os seus descendentes, estaria plantando a semente da divisão e discórdia em sua posteridade, o que seria uma ação equivalente à pusilanimidade de tiranos. ${ }^{28}$ Por outro lado, se Deus não reservasse a um rei nenhuma descendência direta e legítima, este não poderia trapacear com os parentes mais próximos e legítimos na linha de sucessão, pois, como os reinos seriam dispostos por Deus, não caberia ao Rei (ou ao povo) desapossar um herdeiro legítimo - e herdeiros legítimos seriam, nesse caso, parentes colaterais (tal como James e seu filho em relação ao trono da Inglaterra) em vez de bastardos.

\section{Civilizando os dois corpos do Rei}

O terceiro livro de Basilikon Doron gira em torno de um ponto para o qual converge tudo o que foi abordado nos dois livros anteriores: tratam-se das formas e meios pelos quais um rei deveria figurar a sua pessoa moral (persona ficta) e a sua pessoa privada (corporeidade físico-humoral) perante os seus súditos e serviçais. Para tratar desse assunto, James lança mão da tópica do "teatro do mundo", para lembrar ao príncipe que deveria agir como se estivesse num palco, em que todas as pessoas o contemplam no exercício de seu ofício. Com isso, pretendia lembrar-lhe que as pessoas iriam julgar a sua substância conforme a sua aparência externa em diferentes circunstâncias, ou seja, seria a partir de suas ações, escolhas e seus gestos que os súditos e os serviçais mais próximos iriam deduzir as suas intençôes e qualidades. Daí, na ação do rei, não deveria haver meio-termo entre vício e virtude, da mesma forma que não haveria meio-termo entre Céu e Inferno. Afinal, os apetites de um rei em coisas menores pode- 
riam revelar o seu caráter no trato das coisas maiores que viessem a interferir na vida da Commonwealth. Disso se seguem várias outras orientações de etiqueta ou figuração de si.

Quando estivesse comendo, por exemplo, um rei deveria evitar dois extremos: a incivilidade ou grosseria dos cínicos e a afetação afeminada das damas delicadas. Um rei deveria comer de forma viril, cordata e honesta, assim como não deveria fazer despachos durante as suas refeições, pois não haveria como ser pensativo nessas ocasiōes. Em todo caso, James recomenda que a "dieta" (alimentícia, esportiva e sexual) de um rei deveria sempre se acomodar aos negócios do Estado, em vez do contrário. Afinal, se todo homem deveria evitar toda sorte de excessos e, muito particularmente, a embriaguês, que é um vício bestial que cresce com a idade, todo excesso seria muito mais censurável e visível quando se manifestasse em reis. ${ }^{29}$

$\mathrm{Na}$ figuração de si, tanto em comportamento quanto em gestos e vestimenta, um rei deveria manter uma forma inter Togatos \& Paludatos: como Togatos, deveria manter a gravidade de um Juiz que faz e profere a Lei; como Paludatos, deveria manter a leveza/destreza do cavalheiro que porta o poder da Espada. Por outro lado, lembra James, o ofício régio seria também um meio-tempo entre os estados Civil e Eclesiástico, pois um rei não seria um mero laicus, como acreditavam os "papistas" e "anabatistas" - o mesmo erro para o qual se inclinariam, segundo James, os puritanos.

Aliás, sem que houvesse propriamente uma regra muito rígida (precise) para regular tal assunto, um rei deveria vestir-se de acordo com as estações do ano, a sua posição, as circunstâncias e a sua idade, evitando ser afeminado em suas roupas, seus perfumes e enfeites, assim como não deveria usar cabelos e unhas longas, pois seriam "excrementos da natureza”. James recomenda também que um rei e sua Corte não deveriam portar armas vulgares junto de suas roupas, sendo nobre e honrável usar adagas e floretes em bom estado de conservação. No entanto, o príncipe deveria banir (da Corte e do País) todo tipo de arma proibida pelas leis, como pistolas e outras semelhantes (ofensivas ou defensivas) de fácil ocultação nas roupas.

Outro assunto em que James se detém diz respeito à forma de falar e aos gestos que a acompanham. Para proceder do modo que seria adequado a um rei, James recomenda que seu filho seja "natural e claro em sua eloquência" ("vse a naturall and plaine forme"), evitando "formas afetadas" ("affectate formes") em seus gestos e suas palavras. Assim, em sua linguagem, um rei deveria ser direto, honesto, atraente, claro, breve e sentencioso, evitando termos e expressões grosseiras ou afeminadas, chistes licenciosos ou jargóes tirados de livros vulgares de aforismos ou máximas ("not vsing any rusticall corrupt leide, as bookelanguage, and pen and inke-horne termes: and least of all mignard and effoeminate tearmes").

Segundo James, a melhor eloquência para um rei consistiria em demonstrar seus pensamentos de forma natural, clara e sensivel (i.e., atenta às circunstâncias), posto que construídos, tal como recomenda Cícero, a partir de fundamentos bons e corretos. Por isso, um rei deveria temperar a sua exposição e seus gestos com gravidade, ligeireza ou alegria, de acordo com o assunto, interlocutor, ocasião e costumes do país, não devendo escarnecer de matérias teológicas ou profanar as Escrituras durante banquetes, cerimônias à mesa e festas da Corte.

James também lembra a seu filho a importância de distinguir a sua forma de linguagem quando estivesse fazendo reflexôes na condição de homem particular ou aluno, de modo a não se confundir com a sua linguagem quando estivesse no exercício de seu ofício, pois a modulação da fala e os gestos deveriam mudar quando estivesse pronunciando sentenças, declarando julgamentos ou qualquer outro ponto de seu ofício. Assim, é importante estabelecer essa distinção, pois, na condição de homem particular que elabora algumas reflexôes, o rei ou o príncipe poderia sofrer alguma contestação de sua audiência, sem que isso diminuísse a majestade de sua autoridade. $\mathrm{O}$ mesmo tipo de advertência valeria para os seus Juízes e Magistrados.

James define a escrita como forma de registrar o discurso, e, por isso mesmo, alguns procedimentos deveriam ser seguidos nas proclamações e missivas régias, especialmente quando dirigidas para prín- 
cipes estrangeiros. Nesse caso, James recomenda que sejam breves e claras, mas de estilo gracioso. Por outro lado, se o futuro rei tivesse algum pendor para escrever obras literárias, fossem em verso, fossem em prosa, não deveria fazê-lo a ponto de negligenciar o ofício para o qual recebera o chamado de Deus. E como os escritos de um rei permanecerão como efetivas imagens de sua mente para toda a posteridade, deveria cuidar para que estivessem livres de toda "desonestidade e anormalidade".

Assim, se um príncipe ou rei compóe nobremente, deve buscar assuntos que estejam à sua altura, que não estejam repletos de coisas vãs, mas sim de virtude, devendo evitar obscuridade e deleitar-se de ser claro e sensivel (i.e., atento às circunstâncias). James chega mesmo a dar dicas de estilo para seu filho no que se refere à escrita em versos: ele lembra que a parte principal de um poema não é rimar corretamente ou florear seus versos com muitas palavras belas, pois o que verdadeiramente recomendaria um poema - mesmo transpondo os seus versos para prosa - seria o fato de permanecer rico em invenções ligeiras e floreios poéticos que contenham comparações belas e pertinentes. Além disso, embora pessoalmente versado em grego e latim, James recomendaria que o príncipe escrevesse em sua própria língua, pois tudo o que deveria ser dito em grego ou latim já foi feito. Ademais, seria importante um rei purificar e tornar famosa a sua própria língua.

Além das atividades intelectuais, James afirma que um príncipe jovem deveria dispensar algum tempo para exercícios físicos, praticando passatempos e jogos honestos que ajudassem a manter o seu corpo saudável. Desse modo, poderia banir o ócio (a mãe de todos os vícios) de sua mente e tornar o seu corpo mais forte, hábil e resistente para viagens, que seriam muito necessárias para um rei conhecer o seu reino e seus súditos. Por isso mesmo, os jogos mais honrosos e recomendáveis para um rei seriam: cavalgar e praticar a caça com "running hounds" (raça de cães de caça adequados à sua elevada posição social e condição viril).

No entanto, não se deveria praticar a caça ao modo dos ladrões, ou seja, com armas de fogo, arco-flecha e "greyhounds" (raça de cães do grupo hound que seria própria para camponeses), pois isso retiraria do jogo todo o seu caráter marcial e apropriado à grandeza régia. James também recomenda outras formas de exercícios ou jogos de campo, contanto que o príncipe os praticasse moderadamente e "não os transformasse em profissão" ("not making a craft of them"): corrida, salto, "luta grega”, esgrima, dança, tênis (de campo aberto ou fechado), arco-flecha, "bilhar de campo" etc. ("running, leaping, wrastling, fencing, dancing, and playing at the caitch or tennise, archerie, palle maille, and such like other faire and pleasant fieldgames"). Outro jogo que James concede ao príncipe praticar é a falconaria, mas adverte que não deveria ser praticado com muita frequência, pois é menos parecido com a guerra do que a caça.

Como podemos notar, desde as atividades intelectuais e artísticas até as esportivas, a regra geral é sempre a mesma: o príncipe ou rei deveria envolver-se em atividades intelectuais e esportivas de acordo com sua idade e que pudessem servir para capacitar ou aperfeiçoar as suas habilidades particulares para o cumprimento dos deveres específicos de seu ofício. Por isso mesmo, diferentemente de outros homens sábios de seu tempo, James não proíbe ou condena completamente a prática dos jogos de mesa (dados, cartas e demais jogos de azar), desde que praticados moderadamente como breves passatempos, particularmente quando a idade, estação ou o clima impedisse a prática dos jogos de campo, ou quando o príncipe, não tendo outra coisa para fazer (o que, segundo James, deveria ser coisa muito rara num bom rei), estivesse cansado de leituras. Em todo caso, desde que não envolvessem mentiras, falsidades ou trapaças, os jogos de mesa exercitariam o engenho do rei no julgamento de matérias pouco claras, sem qualquer prejuízo moral ou teológico.

Segundo James, um rei deveria saber escolher as suas companhias conforme as ocasióes, distinguindo aquelas que são adequadas para exercícios e jogos daquelas que servem para os negócios graves e honestos. Daí, de forma análoga àquilo que afirmara anteriormente em relação às refeiçōes régias, James recomenda que um rei nunca deveria fazer seus despachos durante a prática da caça ou de outros jogos. Em todo caso, durante as suas práticas de recreação, um rei deveria escolher a companhia de pessoas 
honestas, evitando a companhia de personalidades infames e viciosas que misturassem matérias sujas e alegres em suas conversações, o que incluiria, muito particularmente, companhias femininas, principalmente antes do casamento.

Disso tudo decorria a afirmação de que um bom rei não poderia transformar os seus companheiros de esporte e recreação em seus conselheiros e, muito menos, deleitar-se com a companhia de comediantes e cantadores de baladas - conforme o código social clássico, a comédia seria um gênero baixo e, portanto, próprio para pessoas vulgares. Aliás, James lembra que seriam os tiranos que se comprazeriam em glorificar-se como autores e atores de comédias e tragédias. Além disso, James afirma que um bom rei nunca deveria comprazer-se ou glorificar-se por ser muito bom no desempenho de qualquer arte mecânica ("mechanicke craft"), nem de ser um bom tocador de instrumentos musicais ("player vpon instruments"), particularmente aqueles que os homens comuns utilizavam para ganhar a vida.

Ao final de Basilikon Doron, por meio de analogias e sinédoques moral-anatômicas do corpo físico do rei em relação ao seu corpo místico do Rei, James lembraria a seu filho que as principais instruçôes para a condução dos negócios da Commonwealth iriam se encontrar no próprio microcosmo do seu corpo: se o príncipe possui dois olhos, estes significariam previsão e providência, com um aguçado olhar atento para todas as coisas; os dois ouvidos significariam paciência de ouvir todas as partes num julgamento; a língua, que é única, serviria para pronunciar sentenças claras, sensíveis e uniformes; o coração, que também é único, serviria para manter uma resolução uniforme e constante, de acordo com a apreensão tida do processo; as duas mãos e os dois pés, com seus muitos dedos, significariam rapidez na execução das deliberações régias, empregando todos os meios necessários para efetivá-las.

\section{Conclusão}

A condição de poder soberano na estrutura política e religiosa da Inglaterra e Escócia da última década do século XVI criava dilemas bem específicos para a figuração da dignidade régia - dilemas que vemos James I enfrentar por meio de um repertório de tópicas críticas que retoricamente nivelava puritanos e papistas como ameaças à paz civil e à sacralidade específica do poder régio. Em Basilikon Doron, James demonstra que um rei, para figurar corretamente as leis da Commonwealth, deveria temperar os seus efeitos conforme as circunstâncias (i.e., não ser over precise), combater as práticas de vingança e a arrogância de súditos insolentes que tomavam para si o poder de julgar, punir e pregar à revelia do soberano.

Portanto, (1) a condenação ou demonização da vingança, dos duelos e dos súditos que praticavam o sacerdócio universal (e/ou negavam a infalibilidade da Bíblia em nome da "luz interior"), (2) a individuação ético-jurídica na relação entre leis e penas, assim como, (3) a casuística deliberativa régia em face aos costumes e privilégios de territórios, coletividades de habitantes, famílias e indivíduos demonstrariam o quanto o pensamento teológico-político jacobita operava - a partir dos dilemas especificos de autoridade e sacralidade dos reis na Inglaterra e Escócia de finais do século XVI - com uma concepção estatal das instituiçôes político-jurídicas e dos vínculos de interdependência social que seria própria do Antigo Regime na Europa. Tal concepção de Estado justamente se reportava a um novo ethos nas práticas sociais, políticas e jurídicas.

James expressava tal ethos, por exemplo, ao afirmar que, quando um particular cometia um crime contra outro particular, o prejuízo imediato seria da parte ofendida; no entanto, quando a parte ofendida se vingava por seus próprios meios, o prejuízo imediato seria da autoridade régia, pois significava que um particular tomou para si o atributo régio de julgar e punir em nome da Commonwealth. Como sabemos, esse pressuposto é repetido não apenas em espelhos de príncipes como Basilikon Doron, mas também na forma como as peças teatrais elizabethanas e jacobitas sempre caracterizam, em chave moralmente condenatória, todos os personagens que, tomados pela fúria insensata, pelo humor de vingança ou pela vanglória guerreira, caíam na insolência arrogante ao tomarem para si a prerrogativa régia de julgar e punir. ${ }^{30}$ 
Todas essas obras apontam para um novo horizonte moral, em que os príncipes deveriam ser sábios guerreiros e políticos, pois, agora, o seu corpo físico-humoral e o seu engenho deveriam ser refinados e condicionados para o serviço de figurar adequadamente uma dignidade institucional pública, que fora concebida por Deus e revelada na Bíblia para proteger as pessoas e seus bens depois da Queda. Nesses termos, uma jovem alteza social não poderia reduzir a sua existência a simplesmente realizar seus gostos e suas fantasias pessoais de mando, vingança ou glória guerreira. Assim, mesmo a palavra empenhada de um rei deveria seguir o que seria conveniente para a segurança pública, pois um poder soberano nunca jura enquanto pessoa privada, mas sim enquanto dignidade institucional pública.

Ora, essa mudança de paradigma moral na forma de figurar a realeza significava, na prática, que a glória guerreira pessoal (ethos dominial-estamental) tornava-se anacrônica diante da demanda de adequação (hu)moral da nobreza à função politica (ethos estatal-estamental). Portanto, os espelhos de príncipes e as peças teatrais elizabethanas e jacobitas apontavam para uma expectativa (hu)moral que pressupunha o fim do ethos guerreiro feudal (e das vinganças coletivas vicinais, clânicas, dinásticas ou familiares) e a emergência de patamares de pudor e subjetividade mais adequados a uma lógica estatal-estamental de instituições políticas, práticas jurídicas e de configuração de vínculos de interdependência social.

Assim, envolvidos numa aura sacrificial que se confundia com a proteção da res publica (Commonwealth), cobrados fisicamente e (hu)moralmente para se subordinarem à sacralidade do ofício régio (sinédoque da res publica), os príncipes modernos, principalmente em chave teológico jacobita-episcopal, não poderiam ser entendidos pelos súditos como mero laicus, como pretendiam os "puritanos" - pelo menos, tal como estes são estereotipados no discurso de James I -, e menos ainda deveriam se subordinar aos ditames de papas e bispos arrogantes e hipócritas. ${ }^{31}$ Em todo caso, um bom rei deveria saber refrear as suas paixões pessoais para se adequar a tudo que a função régia (persona moral/pública) exigia de seu corpo e sua mente, para, desse modo, figurar publicamente a aura divina de seu oficio.

Enfim, o que vemos em Basilikon Doron é mais um exemplo de espelho de príncipe que visa a instruir as jovens altezas sociais no sentido de prevenirem, em diferentes escalas de prática social e política, a desfiguração do corpo místico do Estado. No caso específico do pensamento jacobita, isso significava não apenas lembrar ao príncipe como se figurar conforme as expectativas da dignidade institucional de seu ofício, mas também identificar as ameaças internas e externas que pretendiam diminuir ou anular a deferência à sacralidade de sua específica posição de autoridade, nomeadamente, os "puritanos" e os "papistas".

\section{Notas}

${ }^{1}$ A ediçãao que serve de base para este estudo é: JAMES I. "Basilikon Doron”. In: McILWAIN, Charles Howard (ed.).Political Works of James I. Cambridge: Harvard University Press, 1918, p.3-52.

${ }^{2}$ DOELMAN, James. King James I and the Religious Culture of England. Rochester/NY: D.S. Brewer, 2000. Ver também: ERASMUS, Desiderius. Education of a Christian Prince. New York: Octagon Books, 1963.

${ }^{3}$ HILL, Christopher. O mundo de ponta-cabeça: ideias radicais durante a Revolução Inglesa. São Paulo: Companhia das Letras, 1991, p. 156-186.

${ }^{4}$ HAIGH, Christopher. English Reformations: Religion, Politics, and Society under the Tudors. Oxford: Oxford University Press, 1993.

${ }^{5}$ Desde 1568, Mary Stuart (1542-1587) era cativa na Inglaterra e fora acusada, em 1586, de conspirar o assassinato da rainha Elizabeth, sendo decapitada em 8 de fevereiro de 1587. No entanto, a desgraça política da mãe de James I começou muito antes disso: com apenas 18 anos, tornara-se a rainha-viúva de Francisco II (1544-1560) da França, depois do falecimento do jovem rei em 5 de dezembro de 1560. Ao retornar da corte francesa para a Escócia, em 1561, manteve uma política de tolerância religiosa. Em 1565, contraiu segundas núpcias com Henry Stuart (1545-1567), conde de Darnley, com quem concebera James, que nasceu em 19 de junho de 1566. No entanto, o casamento não fora bem recebido na Inglaterra, pois Elizabeth era contrária ao casamento de Mary com um membro do tronco colateral Tudor. Desde o seu retorno à Escócia, Mary Stuart demonstrava pretensões ao trono da Inglaterra. No entanto, o seu casamento também representou a ascensão, na corte da Escócia, dos nobres da família Lennox, à qual pertencia o conde de Darnley. Em março de 1566, quando houve, perante a rainha, o assassinato de seu secretário e confidente, David Riccio (1533-1566), Mary entendeu que poderia ser o próximo alvo se não estivesse grávida. Assim, com o apoio de seu suposto amante, James Hepburn (1535-1578), 
conde de Bothwel, a rainha conspirou o assassinato do seu marido. Na noite de 9 de fevereiro de 1567, o pai de James morreu em situação inconclusiva. Três meses depois, Mary casaria com Bothwell, mas, em 15 de junho de 1567, foi presa na pequena ilha de Loch Leven, sendo formalmente deposta em favor do infante James, que fora sagrado rei da Escócia em 24 de julho de 1567. Em 1568, depois de um breve período de liberdade, Mary tentou conspirar para retornar ao trono da Escócia, mas foi derrotada, sendo obrigada a fugir do país em meados de maio, quando, impulsivamente, buscou refúgio na Inglaterra, sendo mantida cativa pela rainha Elizabeth desde então. Em 1586, Mary Stuart foi acusada de conspirar o assassinato de Elizabeth I, com apoio papal e do rei Felipe II (1527-1598) da Espanha. É importante lembrar que Felipe II fora marido da meia-irmã mais velha de Elizabeth, Maria I (1516-1558), e pleiteava o trono da Inglaterra desde a morte da Maria I, que fora sucedida por Elizabeth. Depois desse episódio, Elizabeth entendeu que Mary Stuart seria uma permanente ameaça à estabilidade de seu poder e, por fim, ordenou que fosse decapitada por conspirar o seu assassinato. Depois disso, Felipe II tentou invadir a Inglaterra e depor Elizabeth, mas sofreu uma infamante derrota em 1588, o que destruiu o mito de sua Armada Invencivel. Todas essas informações são importantes para entendermos os exemplos que James I enfatizará para seu filho em Basilikon Doron.

${ }^{6}$ Durante a sua menoridade, James teve sucessivos regentes: os condes de Moray, Lennox, Mar e Morton. Moray, também chamado James, era meio-irmão de Mary Stuart, mas era bastardo e havia perdido influência na corte escocesa quando Mary casara-se com seu primo Henry Stuart, conde de Darnley, membro da família Lennox. Os períodos de menoridade régia são sempre conturbados para a estabilização de redes clientelares efetivamente favoráveis ao rei, pois muitas famílias nobres disputam entre si o posto de regência.

${ }^{7}$ A partir das seguintes edições: CALVINO, João. A instituição da religião cristã, t.2. São Paulo: Unesp, 2009; CALVIN, John. Commentaries to Bible. Disponível em <www.ccel.org/c/calvin>.

${ }^{8}$ DIEHL, Huston. "Infinite Space”: Representation and Reformation in "Measure for Measure”. Shakespeare Quarterly, v. 49, n. 4, p. 393-410, 1998; WARD, David. The King and Hamlet. Shakespeare Quarterly, v. 43, n. 3, p. 280-302, 1992.

${ }^{9}$ Aliás, no terceiro livro de Basilikon Doron, depois de uma série de considerações sobre companhia e habilidades régias, James retoma o tema da acessibilidade à pessoa régia: para aumentar a sua majestade, um rei não deveria facilitar o acesso à sua pessoa a todo tempo, mas também não deveria agir como os reis da Pérsia, que se trancavam e afastavam-se de seus súditos. Tal como em outros espelhos de príncipes de sua época, James fazia a mesma associação retórica (estereotipada) entre "soberanos persas" ("mouros" ou "turcos") e tirania idólatra. Como alternativa às formas "bárbaras" e "idólatras" de corte, James propõe que um bom rei deveria sempre agir com razão, apontando horas específicas para audiências públicas.

${ }^{10}$ VIANNA, Alexander Martins. Sobre a relação entre Rei, Lei e Parlamento no Antigo Regime. Espaço Acadêmico, n. 112, p. 67-75, 2010. Disponível em <http://periodicos.uem.br/ojs/index.php/EspacoAcademico/article/viewFile/10785/5970>. Acesso em 12-11-2010.

${ }^{11}$ ASCH, Ronald; DUCHHARDT, Heinz (eds.). El Absolutismo: Un Mito? Barcelona: Idea Books, 2000; HARRISS, Gerald. Political Society and the Growth of Government in Late Medieval England. Past \& Present, n. 138, p. 28-57, 1993; HESPANHA, António Manuel. Cultura Jurídica Européia - Síntese do Milênio. Lisboa: Europa-América, 2003; HESPANHA, António Manuel (Org.). Justiça e litigiosidade: história e prospectiva. Lisboa: Calouste Gulbenkian, 1993; LOADES, David. Tudor Government: Structures of Authority in the Sixteenth Century. Oxford/Malden: Blackwell, 1997; VIANNA, Alexander M. Absolutismo: os limites de uso de um conceito liberal. Revista Eletrônica Urutágua, n. 14, (s/d), 2007. Disponível em <http://www.urutagua.uem.br/014/14vianna.htm>. Acesso em 12-11-2010; VIANNA, Alexander Martins. A distinção enciclopediana entre "Monarquia Absoluta" e "Despotismo". Espaço Acadêmico, n. 83, (s/d), 2008. Disponível em <http://www.espacoacademico.com.br/083/83vianna.htm>. Acesso em 12-11-2010.

${ }^{12}$ Podemos observar, em chave austera, este tema ser tratado por Lutero em seu sermão "Sobre a autoridade secular" (1523), mas também na edição de 1559 de Instituição da religião cristã, de Calvino (capítulos XI, XII e XIII do quarto livro). Em chave cômica, explorando os mesmos motivos que observamos nas obras de Lutero, Calvino e James I, observamos o tema do uso "over precise" da lei ser explorado na peça shakespeareana Medida por medida. Segundo Alvin Kernan, esta peça fora encenada no Whitehall em dezembro de 1604, ou seja, poucos meses depois da polêmica de James I com os puritanos em Hampton Court. Ver KERNAN, Alvin. Shakespeare, the King's Playwright: Theater in the Stuart Court, 1603-1613. New Haven \& London: Yale University Press, 1995. p. 50-70. Ver também DIEHL, Huston. "Infinite Space”: Representation and Reformation in "Measure for Measure". Shakespeare Quarterly, v. 49, n. 4, p. 393-410, 1998.

${ }^{13}$ Supra nota 5.

${ }^{14}$ KASTAN, David Scott. "Proud Majesty made a subject: Shakespeare and the Spectacle of Rule". Shakespeare Quarterly, v. 37, n. 4, p. 459-475, 1986.

${ }^{15}$ LUTERO, Martinho. Sobre a autoridade secular. São Paulo: Martins Fontes, 1995.

${ }^{16}$ Como notara Keith Thomas, a maioria dos escritores mais requintados dos séculos XVI e XVII desprezava as profecias. Aliás, durante a primeira sessão do Parlamento sob o reinado [1485-1509] de Henrique VII (1457-1509), todos os tipos de profecias tinham sido classificados como crime, mas foram Henrique VIII (1491-1547) e seus sucessores protestantes que tomaram medidas mais firmes contra qualquer tipo de profecia política: uma lei de 1541/1542 declarava criminosas todas 
as pessoas que buscassem prever o futuro daqueles que tinham certos animais em seus símbolos heráldicos, assim como fazer profecias a partir das letras em seus nomes; essa lei foi revogada em 1547, porém, em 1549, no início do curto reinado [1547-1553] de Eduardo VI (1537-1553), outra lei impusera multas e penas de prisão àqueles que fizessem circular profecias com a intenção de provocar rebeliōes ou perturbações à ordem civil; essa lei foi relaxada com a ascensão ao trono de Maria I (1516-1558), mas foi renovada por um estatuto de 1563 do reinado [1558-1603] de Elizabeth I (1533-1603). Ver THOMAS, Keith. Religião e o declinio da magia. São Paulo: Companhia das Letras, 1991. p. 322-323.

${ }^{17}$ VIANNA, Alexander Martins. A desfiguração do corpo político em "Ricardo III". História em Reflexão, vol.6, n. 3, p. 1-29, 2009. Disponível em <http://www.periodicos.ufgd.edu.br/index.php/historiaemreflexao/article/view/478/348>. Acesso em 12-11-2010.

${ }^{18}$ Veremos, mais adiante, que tal tema se desdobra na forma que o rei James I define como deveria ser as companhias e conselhos do príncipe.

${ }^{19}$ Para um estudo histórico-literário comparativo das tópicas do rei sacrificial e pai protetor dos súditos, ver: BERCÉ, YvesMarie. O rei oculto: salvadores e impostores. Mitos políticos populares na Europa Moderna. São Paulo: EDUSC/Imprensa Oficial de São Paulo, 2003.

${ }^{20}$ Ao longo de seu discurso, James I aciona várias vezes o motivo retórico do microcosmo do corpo orgânico como metáfora ou sinédoque do corpo político, o que significa a expectativa da necessária relação complementar e equilibrada entre humores/potências desiguais. Nesses termos, um rei da justiça/equidade deverá saber conter os afectos (as paixões) de si e dos súditos que pudessem conturbar a ordem pública, criando unidade através da desigualdade entre os súditos. Daí, qualquer demanda por igualdade seria entendida como desagregadora do corpo político. Portanto, tornar o corpo político pensável a partir do motivo retórico do microcosmo do corpo orgânico tem como consequência a metaforização como "doença/enfermidade" de tudo aquilo que pudesse conturbar o equilíbrio (hu)moral da estrutura de autoridade do corpo político.

${ }^{21} \mathrm{Na}$ Escócia e na Inglaterra, uma "regalia" correspondia a uma circunscrição jurisdicional que somente poderia ser criada pelo rei, que garantia domínios jurisdicionais a um súdito nobre in liberam regalitatem, o que lhe conferia jurisdições (civil e criminal) equivalentes aos xerifes régios, mas eram mais extensíveis em matérias criminais, pois tornavam a corte dominial equivalente à Alta Corte Régia de Justiça. Desse modo, o portador de uma "regalia" tinha um amplo arco de poder jurisdicional, o que o colocava, na maior parte das matérias de justiça, com exceção dos casos de traição, na posição de última instância de recurso. Além disso, no caso de uma baronia estar inserida numa "regalia”, o portador dessa jurisdição poderia exercer seu poder sobre os barôes, não cabendo recurso ao rei - com exceção, como já se apontou, dos casos de traição. Como desde o século XIV houve a tendência de os "senhores de regalias" usurparem a autoridade régia, exercendo uma autoridade local quase independente, isso explicaria a solução proposta por James I ao final do século XVI: não conceder, na Escócia, novas "regalias" em caráter hereditário à medida que fossem vagando por interrupção de descendência masculina direta. $\mathrm{O}$ parlamento britânico aboliria as regalias somente em 1746 .

22 Não por acaso, os puritanos eram recorrentemente estereotipados na Inglaterra, em chave cômica, nas peças teatrais do solace régio. Ver VIANNA, Alexander Martins. O papel da imagem no combate reformado contra a idolatria e pela consciência. Revista Eletrônica Urutágua, n.16, p. 55-64, 2008. Disponível em <http://periodicos.uem.br/ojs/index.php/Urutagua/ article/viewFile/3958/3277>. Acesso em 12-11-2010.

${ }^{23}$ Aliás, vale lembrar que, nas peças shakespeareanas Ricardo III e Macbeth, personagens da realeza que se fiam em profecias cometem várias injustiças, com desenlaces necessariamente sangrentos. O rei Eduardo IV (em Ricardo III) e o rei usurpador Macbeth, por exemplo, têm uma marca moral negativa comum: deixam-se conduzir por mulheres elou nobres bajuladores.

${ }^{24}$ Antes do surgimento do tema da "economia política" entre os doutos da segunda metade do século XVIII, quando, definitivamente, foram levantadas críticas que afirmavam que as rei familiariae não poderiam servir como modelo administrativo da res publica (Commonwealth), era um componente obrigatório da boa figuração de rei, nos tratados de governo dos séculos XVI e XVII, estabelecer um vínculo implicativo, ou jogo de espelho, entre bom governo e reprodução da Casa Régia (O economia) e bom governo e reprodução da coisa pública (Política), pois a Casa Régia deveria figurar-se exemplarmente como a sinédoque ou metonímia do Reino. Ver: FRIGO, Daniela. “Disciplina Rei Familiariae”: a Economia como Modelo Administrativo de "Ancien Regime". Penélope, n. 6, p. 47-62, 1991; ELIAS, Norbert. Sociedade de corte. Rio de Janeiro: Jorge Zahar, 2001; ROUSSEAU, J.-J. Economia (Moral e Política). In: DIDEROT \& D’ALEMBERT. Verbetes Políticos da Enciclopédia. São Paulo: UNESP, 2006. p. 83-127.

${ }^{25}$ Embora não afirme explicitamente, há aqui uma alusão aos erros político de Mary Stuart, que manteve David Riccio (1533-1566) como seu secretário e confidente. Supra nota 5.

${ }^{26}$ Sobre a visão protestante de casamento na Inglaterra dos séculos XVI e XVII, ver: FLETCHER, Anthony. The Protestant Idea of Marriage in Early Modern England. In: FLETCHER, Anthony et alii. Religion, Culture and Society in Early Modern Britain. Cambridge: Cambridge University Press, 2006, p.161-181.

${ }^{27}$ Ironicamente, o primogênito de James, Carlos I (1600-1649), casaria, em 1623, com Henriqueta Maria (1609-1669), irmã do rei Luís XIII (1601-1643) da França. Tal casamento não ocorreria sem o consentimento de James I (1566-1625). Depois da morte de James I, Henriqueta de Bourbon - agora rainha - passou a professar abertamente a sua religião na corte régia e, ao que parece, com a tácita anuência de seu marido. Isso foi mais um fator que desgastou a imagem régia perante 
os seus súditos puritanos mais rigoristas. Ver MORRIL, John. The Stuarts, 1603-1688. In: The Oxford Illustrated History of Britain. Oxford/New York: Oxford University Press, 1992, p. 286-351.

${ }^{28}$ Alvin Kernan fez um trabalho minucioso que justamente demonstrava o interesse de James, já como rei na Inglaterra, pela peça Rei Lear, que teria sido encenada, por exemplo, em Whitehall no natal de 1606. Ver KERNAN, Alvin. Shakespeare, the King's Playwright: Theater in the Stuart Court, 1603-1613. New Haven \& London: Yale University Press, 1995. p. 89-105. Paradigmaticamente, ocorre a divisão do reino entre as herdeiras de Lear na primeira cena da peça. A caracterização de Lear como rei senil desejoso de bajulação, quando colocado em contraste (hu)moral com o caracter Cordélia, acentua a sua figuração cênica como pusilânime tirânico.

${ }^{29}$ Alvin Kernan também aponta para a possibilidade de James I ter um interesse específico pela peça Hamlet, que teria sido encenada, por exemplo, em Hampton Court no natal de 1603. No início da peça, o rei usurpador Cláudio é figurado seguindo o estereótipo da corte dinamarquesa na literatura britânica - como o pivot de uma corte de "nobres embriagados festivos", quebrando o luto pelo rei morto, que era seu irmão mais velho e pai do príncipe Hamlet. Ver: KERNAN, Alvin. Shakespeare, the King's Playwright: Theater in the Stuart Court, 1603-1613. New Haven \& London: Yale University Press, 1995. p. 24-49; WARD, David. The King and Hamlet. Shakespeare Quarterly, v. 43, n. 3, p. 280-302, 1992.

${ }^{30}$ HATTAWAY, Michael. Blood is their argument: men of war and soldiers in Shakespeare and others. In: FLETCHER, Anthony; ROBERTS, Peter (eds.). Religion, Culture and Society in Early Modern Britain. Cambridge: Cambridge University Press, 1994. p.84-10. Ver também HOLMER, Joan Ozark. "Draw, if you be men”: Saviolo's significance for "Romeo and Juliet”. Shakespeare Quarterly, v. 45, n. 2, p. 163-189, 1994. GIDDENS, Eugene. Honourable Men: Militancy and Masculinity in Julius Caesar. Renaissance Forum, v. 5, n. 2, p.(s/d), 2001. Disponível em <http://www.hull.ac.uk/renforum/v5no2/ giddens.htm>. Acesso em 12-11-2010.

${ }^{31}$ Em Leviathan (1651), por exemplo, Thomas Hobbes (1588-1679) incluiria os “sofistas/escolásticos" da Universidade de Oxford nesta relação de "ameaças" à ordem civil e ao poder soberano.

\section{Referências bibliográficas}

ASCH, Ronald; DUCHHARDT, Heinz (eds.). El Absolutismo: un Mito? Barcelona: Idea Books, 2000.

BERCÉ, Yves-Marie. O rei oculto: salvadores e impostores. Mitos políticos populares na Europa Moderna. São Paulo: EDUSC/Imprensa Oficial de São Paulo, 2003.

CALVIN, John. Commentaries to Bible. Disponível em <www.ccel.org/c/calvin>.

CALVINO, João. A instituiçãa da religião cristã, t. 2. São Paulo: Unesp, 2009.

DELUMEAU, Jean. Nascimento e afirmação da Reforma. São Paulo: Pioneira, 1989.

DIEHL, Huston. "Infinite Space": Representation and Reformation in "Measure for Measure". Shakespeare Quarterly, v. 49, n. 4, 1998, p. 393-410.

. Staging Reform, Reforming the Stage: Protestantism and Popular Theater in Early Modern England. Ithaca, NY: Cornell University Press, 1997.

DOELMAN, James. King James I and the Religious Culture of England. Rochester: D.S. Brewer, 2000.

ELIAS, Norbert. Sociedade de corte. Rio de Janeiro: Zahar, 2001.

ERASMUS, Desiderius. Education of a Christian Prince. New York: Octagon Books, 1963.

FLETCHER, Anthony et alii. Religion, Culture and Society in Early Modern Britain. Cambridge: Cambridge University Press, 2006.

FRIGO, Daniela. "Disciplina Rei Familiariae": a economia como modelo administrativo de "Ancien Regime". Penélope, n. 6, p. 47-62, 1991.

GARIN, Eugenio (dir.). O homem renascentista. Lisboa: Presença, 1991.

GIDDENS, Eugene. Honourable Men: Militancy and Masculinity in Julius Caesar. Renaissance Forum, v. 5, n. 2, p.(s/d), 2001. Disponível em <http://www.hull.ac.uk/renforum/v5no2/giddens.htm>. Acesso em 12-11-2010.

HAIGH, Christopher. English Reformations: Religion, Politics, and Society under the Tudors. Oxford: Oxford University Press, 1993.

HARRISS, Gerald. Political Society and the Growth of Government in Late Medieval England. Past \& Present, n. 138, p. 28-57, 1993.

HATTAWAY, Michael. Blood is their argument: men of war and soldiers in Shakespeare and others. In: FLETCHER, Anthony; ROBERTS, Peter (eds.). Religion, Culture and Society in Early Modern Britain. Cambridge: Cambridge University Press, 1994. p. 84-101 
HESPANHA, António Manuel (Org.). Justiça e litigiosidade: história e prospectiva. Lisboa: Calouste Gulbenkian, 1993.

HESPANHA, António Manuel. Cultura jurídica européia. Sintese do milênio. Lisboa: Europa-América, 2003.

HILL, Christopher. O mundo de ponta-cabeça: ideias radicais durante a Revolução Inglesa. São Paulo: Companhia das Letras, 1991.

HOBBES, Thomas. Leviathan. Cambridge: Cambridge University Press, 1997.

HOLMER, Joan Ozark. "Draw, if you be men”: Saviolo's significance for "Romeo and Juliet". Shakespeare Quarterly, v. 45, n. 2, p. 163-189, 1994.

JAMES I. Basilikon Doron. In: McILWAIN, Charles Howard (ed.). Political Works of James I. Cambridge: Harvard University Press, 1918. p. 3-52.

KANTOROWICZ, Ernst H. Os dois corpos do Rei. São Paulo: Companhia das Letras, 1998.

KASTAN, David Scott. Proud Majesty made a subject: Shakespeare and the Spectacle of Rule. Shakespeare Quarterly, v. 37, n. 4, p. 459-475, 1986.

KERNAN, Alvin. Shakespeare, the King's Playwright: Theater in the Stuart Court, 1603-1613. New Haven \& London: Yale University Press, 1995.

KOSELLECK, Reinhart. Critica e crise. Rio de Janeiro: UERJ/Contraponto, 1999.

LOADES, David. Tudor Government: Structures of Authority in the Sixteenth Century. Oxford/Malden: Blackwell, 1997.

LUTERO, Martinho. Sobre a autoridade secular. São Paulo: Martins Fontes, 1995.

MARAVALL, José Antonio. Estado Moderno y Mentalidad Social. Madrid: Alianza, 1986.

MORRIL, John et alii. The Oxford Illustrated History of Britain. Oxford/New York: Oxford University Press, 1992.

REYNOLDS, Bryan; WEST, William N. (eds.). Rematerializing Shakespeare: Authority and Representation on the Early Modern English Stage. New York: Palgrave Macmillan, 2005.

ROUSSEAU, J.-J. “Economia (Moral e Política)". In: DIDEROT \& D’ALAMBERT. Verbetes Politicos da Enciclopédia. São Paulo: UNESP, 2006. p. 83-127.

SENELLART, Michel. As artes de governar. São Paulo: Editora 34, 2006.

THOMAS, Keith. Religião e o declínio da magia. São Paulo: Companhia das Letras, 1991.

VIANNA, Alexander Martins. Absolutismo: os limites de uso de um conceito liberal. Revista Eletrônica Urutágua, n.14, p.(s/d), 2007. Disponível em <http://www.urutagua.uem.br/014/14vianna.htm>. Acesso em 12-11-2010.

A desfiguração do corpo político em "Ricardo III". História em Reflexão, vol.6, n. 3, p.1-29, 2009. Disponível em <http://www.periodicos.ufgd.edu.br/index.php/historiaemreflexao/article/view/478/348>. Acesso em 12-11-2010.

. A distinção enciclopediana entre "Monarquia Absoluta" e "Despotismo". Espaço Acadêmico, n. 83, p.(s/d), 2008. Disponível em <http://www.espacoacademico.com.br/083/83vianna.htm>. Acesso em 12-11-2010.

O papel da imagem no combate reformado contra a idolatria e pela consciência. Revista Eletrônica Urutágua, n. 16, p. 55-64, 2008. Disponível em <http://periodicos.uem.br/ojs/index.php/Urutagua/article/ viewFile/3958/3277>. Acesso em 12-11-2010.

. Sobre a Relação entre Rei, Lei e Parlamento no Antigo Regime. Espaço Acadêmico, n. 112, p. 67-75, 2010. Disponível em <http://periodicos.uem.br/ojs/index.php/EspacoAcademico/article/viewFile/10785/5970>. Acesso em 12-11-2010.

WARD, David. The King and Hamlet. Shakespeare Quarterly, v. 43, n. 3, p. 280-302, 1992.

ZARKA, Yves-Charles (Org.). Aspects de la Pensée Médiévale dans la philosophie politique moderne. Paris: PUF, 1999. 


\title{
RESUMO
}

Atualmente, os estudos sobre pensamento político dos séculos XVI e XVII têm valorizado a possibilidade de leituras de textos clássicos fora da chave teleológica da "modernidade política" ou "secularização", o que explica o recente interesse em referenciá-los, mais atentamente, aos seus fundamentos teológicos e ao contexto de embates por autoridade frente ao cisma religioso na Europa desse periodo. Nesse sentido, este ensaio pretende analisar, em chave teológico-politica, os motivos retóricos utilizados por James I na obra Basilikon Doron (1599) para figurar a dignidade régia e as "ameaças" (puritana e papista) à sacralidade da dignidade régia, o que também inclui estudar as proposiçôes e os conselhos régios a respeito dos modos e costumes adequados à constituição da dignitas principesca.

Palavras-chave: auctoritas; Basilikon Doron; Reforma; Antigo Regime.

\begin{abstract}
The studies about $16^{\text {th }}$ and $17^{\text {th }}$ Century Political Thought have currently paid attention of new possibilities of interpretations of classical references without emphasizing teleological approaches as "political modernity" or "secularization". Such a mainstream explains the new interests of studying classical references of $16^{\text {th }}$ and $17^{\text {th }}$ Century Political Thought, but relating them to the background and breakdown of religious and political authorities in Early Modern Europe. So, this article intends to analyse the rhetorical motives used by James I in Basilikon Doron (1599) to represent sacred kingship and to figure its opposites (namely "puritans" and "papists"), also including a study of king's propositions and advices to his son on the ways of fashioning princely manners.

Keywords: auctoritas; Basilikon Doron; Reformation; Ancient Regime.
\end{abstract}

